\title{
Constituents from the Branches of Sambucus si ebol di ana var. pendula with the Properties of Collagen Synthesis Activation
}

\author{
Jun Hwan Yim ${ }^{1}$, Moon Sik Jang ${ }^{1}$, Mi Yeon Moon ${ }^{1}$, Ha Youn Lee ${ }^{1}$, Sung Chun Kim ${ }^{1}$, Nam Ho Lee ${ }^{2 *}$ \\ ${ }^{1}$ Naturalsolution Co., 730-10 Gosan, Namdong, Incheon 405-822, Korea. \\ ${ }^{2}$ Department of Chemistry and Cosmetics, Jeju National University, Jeju 690-756, Korea.
}

\section{ARTICLE INFO \\ Article history: \\ Received on: 02/02/2015 \\ Revised on: 12/02/2015 \\ Accepted on: 21/03/2015 \\ Available online: 27/04/2015}

\section{Key words:}

Sambucus sieboldiana,

collagen, fibroblast, anti-

wrinkle

\begin{abstract}
For the purpose of developing anti-wrinkle cosmetic ingredients, the extracts from branches of a woody plant Sambucus sieboldiana var. pendula were examined on collagen synthesis activities using fibroblast HDFn cells. As a result, the S. sieboldiana ethanol extract (SSE) proved to activate the production of type I procollagen in a dose-dependent manner without showing cell toxicity. Phytochemical study was conducted to isolate the active constituents in the extracts by solvent fractionation followed by chromatographic purifications. From this procedure, two known compounds, kaempferol 3-O-sophoroside (1) and daucosterol (2), were identified by spectroscopic studies. From the isolates, the flavonoid glycoside 1 was verified to induce the synthesis of the type I procollagen dose-dependently. These results suggested that S. sieboldiana extract containing the flavonoid 1 could be useful as an active ingredient in wrinkle-care cosmetics.
\end{abstract}

\section{INTRODUCTION}

Collagen, a fibrous protein, is a major component in the extracellular matrix (ECM) of dermis and responsible for the tensile strength of human skin. Collagen is actually a complex family of 18 proteins, and type I collagen comprises $80-85 \%$ of the overall collagen fiber in the matrix. The amount of collagen I in photo-aged skin is lower than that in normal skin. It is therefore likely that collagen I is the most important type in the skin aging (Baumann, 2002). The wrinkle in the skin is caused by the lack of balance between production and degradation of collagen fiber. The breakdown of the collagen is primarily mediated by the enzyme matrix metalloproteinase-1 (MMP-1) in the dermis. Collagen synthesis is accomplished through a precursor, procollagen, inside the fibroblast cells in ECM. The generated procollagen is secreted into the ECM after hydroxylation of its proline and lysine residues, and finally transformed to collagen fiber by a series of polymerization processes. For the development of the skin anti-aging ingredients in cosmetic applications, one of the major strategies is to find

\footnotetext{
* Corresponding Author

Nam Ho Lee, Department of Chemistry and Cosmetics, Jeju National

University, South Korea.Email: namho@jejunu.ac.kr
}

materials which up-regulate the collagen contents in the dermis (Shuster et al., 1975). In this regard, retinoid compounds are widely used to cure the symptoms of the aged skin by the activation of collagen synthesis as well as by inhibition of MMP-1 expression (Brigstock, 2003). Since the reduced collagen content is recognized as the main cause of the skin wrinkles, much attention is focused on finding natural products with collagen synthesis activating properties for use in anti-aging cosmetic formulations (Lee et al., 2013; Ko et al., 2013). The plant, Sambucus sieboldiana var. pendula (Korean local name: malozum namu), is a deciduous shrub belonging to the Caprifoliaceae family. This tree native to East Asia grows up to $4 \mathrm{~m}$ tall, and its leaves have been used as foods of culinary vegetables. The water extract of S. sieboldiana has been reported to possess anti-inflammatory activities (Cho et al., 1994). In this study, the collagen synthesis activation properties were examined for the ethanol extract of S. sieboldiana branches. In addition, the active constituents were verified by phytochemical investigations.

\section{MATERIALS AND METHODS}

\section{Plant material}

The branches of S. sieboldiana were collected in February of 2013 from Jeju, the island located at the southernmost part of Korea. 


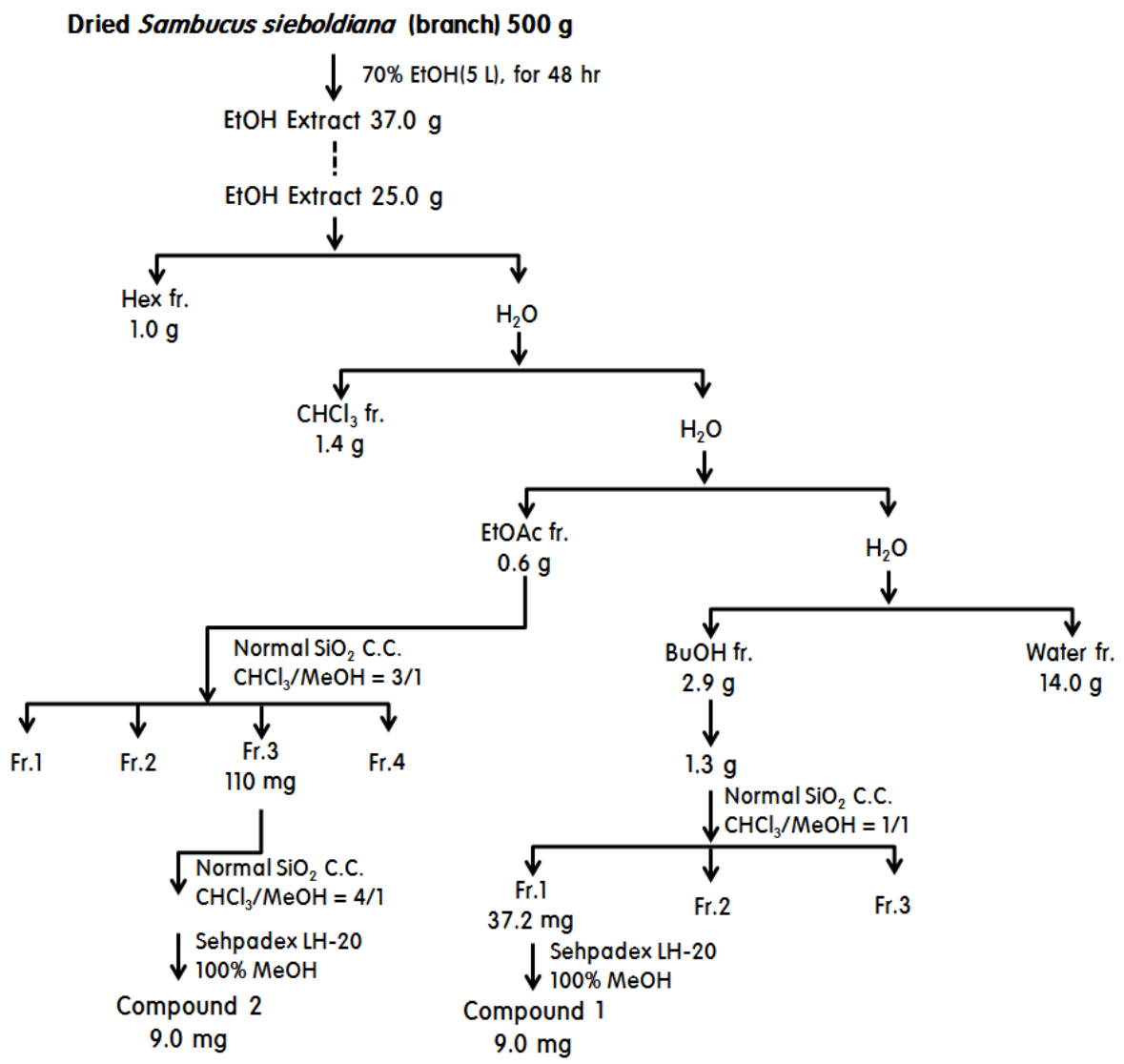

Fig. 1: Isolation scheme of the compounds $\mathbf{1}$ and $\mathbf{2}$ from the extract of S. sieboldiana.

\section{Extraction and isolation}

The air-dried branches of S. sieboldiana (500 g) were extracted with $70 \%$ aq. ethanol (5 L x 2 ) under stirring at room temperature for $48 \mathrm{hr}$. The combined resulting ethanol solutions were filtered, and the filtrate was concentrated using a rotary evaporator at a temperature $40^{\circ} \mathrm{C}$. Part of the ethanol extract $(25.0$ g) was suspended in water and fractionated into $n$-hexane $(1.0 \mathrm{~g})$, chloroform (1.4 g), ethyl acetate (0.6 g), n-butanol (2.9 g) and water $(14.0 \mathrm{~g})$ portions. The ethyl acetate (EtOAc) layer was subjected to normal silica gel column chromatography (CC) eluting with chloroform and methanol, which produced four fractions (S1 to $\mathrm{S} 4)$. The $\mathrm{S} 3$ fraction $(110 \mathrm{mg}$ ) was purified by first passing it through a silica gel $\mathrm{CC}$ using chloroform/ $\mathrm{MeOH}$ (4:1) as eluent, then through Sephadex $\mathrm{LH}-20$ with $\mathrm{MeOH}$ to afford compound $\mathbf{2}$ (9 $\mathrm{mg})$. The $n$-butanol layer was also purified by silica gel $\mathrm{CC}$ using chloroform/MeOH (1:1) and subsequently with Sephadex LH-20 on MeOH to give the compound 1 (9 mg) (Figure 1).

\section{Kaempferol 3-O-sophoroside (1)}

yellow powder; ${ }^{1} \mathrm{H} \quad \mathrm{NMR} \quad\left(\mathrm{CD}_{3} \mathrm{OD}, 400 \mathrm{MHz}\right)$ $\delta 8.08(2 \mathrm{H}, \mathrm{d}, J=7.7 \mathrm{~Hz}), \delta 6.89(2 \mathrm{H}, \mathrm{d}, J=7.7 \mathrm{~Hz})$, $\delta 6.37(1 \mathrm{H}, \mathrm{d}, J=1.8 \mathrm{~Hz}), \delta 6.18(1 \mathrm{H}, \mathrm{d}, J=1.8 \mathrm{~Hz}), \delta 5.32(1 \mathrm{H}$, $\mathrm{d}, \quad J=6.8 \mathrm{~Hz}), \delta 4.74(1 \mathrm{H}, \mathrm{d}, J=6.4 \mathrm{~Hz}) ;{ }^{13} \mathrm{C} \mathrm{NMR}$ $\left(\mathrm{CD}_{3} \mathrm{OD}, \quad 100 \mathrm{MHz}\right) \delta 158.6 \quad(\mathrm{C}-2), 135.0 \quad$ (C-3), 179.9 (C-4),
163.2 (C-5), 100.1 (C-6), 166.5 (C-7), 94.9 (C-8), 158.9 (C-9), 105.7 (C-10), 122.8 (C-1'), 132.5 (C-2'), 116.4 (C-3'), 161.7 (C4'), 116.4 (C-5'), 132.5 (C-6'), 101.6 (C-1'), 80.4 (C-2”), 77.1 (C3"), 70.2 (C-4”), 75.0 (C-5"), 62.0 (C-6”), 104.9 (C-1"'), 75.6 (C2"”), 78.0 (C-3"”), 71.4 (C-4"”), 78.3 (C-5"”) , 62.7 (C-6"”).

\section{Daucosterol (2)}

white powder; ${ }^{1} \mathrm{H} \mathrm{NMR}\left(\mathrm{C}_{6} \mathrm{D}_{5} \mathrm{~N}, 400 \mathrm{MHz}\right) \delta 5.37(1 \mathrm{H}, \mathrm{d}$, $4.5 \mathrm{~Hz}), \delta 5.09(1 \mathrm{H}, \mathrm{d}, J=7.7 \mathrm{~Hz}), \delta 4.10(1 \mathrm{H}, \mathrm{m}), \delta 1.00(3 \mathrm{H}, \mathrm{d}, J$ $=6.4 \mathrm{~Hz}), \delta 0.95(3 \mathrm{H}, \mathrm{s}), \delta 0.91(3 \mathrm{H}, \mathrm{d}, J=7.7 \mathrm{~Hz}), \delta 0.87(3 \mathrm{H}, \mathrm{d}$, $J=7.7 \mathrm{~Hz}), \delta 0.67(3 \mathrm{H}, \mathrm{s}) ;{ }^{13} \mathrm{C} \mathrm{NMR}\left(\mathrm{C}_{6} \mathrm{D}_{5} \mathrm{~N}, 100 \mathrm{MHz}\right) \delta 37.8$ (C-1), 30.6 (C-2), 72.0 (C-3), 40.3 (C-4), 141.2 (C-5), 122.3 (C-6), 32.5 (C-7), 32.4 (C-8), 50.7 (C-9), 37.3 (C-10), 21.6 (C-11), 39.7 (C-12), 42.8 (C-13), 57.1 (C-14), 24.8 (C-15), 28.9 (C-16), 56.6 (C-17), 12.5 (C-18), 19.5 (C-19), 36.7 (C-20), 19.3 (C-21), 34.5 (C-22), 23.7 (C-23), 46.4 (C-24), 29.8 (C-25), 20.3 (C-26), 19.8 (C-27), 26.7 (C-28), 12.3 (C-29), 102.9 (C-1'), 75.7 (C-2'), 79.0 (C-3'), 78.4 (C-4'), 78.9 (C-5'), 63.2 (C-6').

\section{Cell culture}

Primary human foreskin dermal fibroblasts (HDFn cells) were cultured in Dulbecco's modified Eagle's media (DMEM) supplemented with glutamine $(2 \mathrm{mM})$, penicillin $(400 \mathrm{U} / \mathrm{ml})$, streptomycin $(50 \mathrm{mg} / \mathrm{l})$ and $10 \%$ fetal bovine serum (FBS) in a humidified $5 \% \mathrm{CO}_{2}$ atmosphere at $37{ }^{\circ} \mathrm{C}$. 


\section{Procollagen type I protein synthesis test}

HDFn cells ( $5 \times 10^{4}$ cells) were seeded in a 24 well plate with DMEM (containing 10\% FBS and 100 unit/ml penicillinstreptomycin), and were incubated overnight at $37^{\circ} \mathrm{C}$ under $5 \%$ $\mathrm{CO}_{2}$. Test compounds were added to the plate in serum free media, which was incubated 24 hour at $37^{\circ} \mathrm{C}$ under $5 \% \mathrm{CO}_{2}$. The culture supernatant was collected by centrifugation $13,000 \mathrm{rpm}, 4^{\circ} \mathrm{C}, 20$ min. The procollagen type I C-peptide (PIP) was measured according to the supplier's instructions (Takara, MK101).

\section{Cell viability assay}

The cell viability was determined by the MTT assay which is based on the reduction of the soluble yellow MTT tetrazolium salt [3-(4,5-dimethylthiazol-2-yl)-2,5-diphenyl tetrazolium bromide] to its insoluble blue MTT formazan product. This biosynthetic reduction is mediated by mitochondrial succinic dehydrogenase. After treatment with samples, the cells $\left(1 \times 10^{5}\right.$ cells/well) were cultured for 3 days. After washing with PBS, the cells were treated with $200 \mu \mathrm{L}$ of MTT solution $(0.05 \mathrm{mg} / \mathrm{ml})$ and incubated for $4 \mathrm{~h}$ at $37^{\circ} \mathrm{C}$. The supernatant was then removed and $200 \mu \mathrm{L}$ of dimethyl sulfoxide was added to each well to dissolve the formazan product. Wells without cells were used as blanks. Absorbance was determined at $570 \mathrm{~nm}$ using an ELISA reader. The results were expressed as the percentage of control cells.

\section{Statistical analysis}

All data were obtained in triplicate and are represented as means \pm standard error (SE). Significant differences between treatments were determined by the Student's $t$ test in one-way analysis of variance (ANOVA).

\section{RESULTS AND DISCUSSION}

Collagen is the major protein in human skin, and is produced from fibroblast cells in the dermal layer via procollagen protein. The generated procollagen in fibroblast is secreted into the extracellular matrix, and thereafter its C-peptide is dissociated by the procollagen peptidase present in the cell surface. The subsequent polymerization procedures led to the formation of collagen fiber. In this study, human fibroblast cell (HDFn) is treated with S. sieboldiana ethanol extract (SSE), and the amount of collagen production is measured by the procollagen type-I Cpeptide (PIP). The amount of PIP produced was analyzed by ELISA kit.

The experimental result of PIP productions on the treatment of the SSE $(10,50,100 \mu \mathrm{g} / \mathrm{mL})$ to HDFn was summarized in Figure 2. This figure indicates that the PIP content increases in a dose-dependent manner. Compared to the control, the SSE at $100 \mu \mathrm{g} / \mathrm{mL}$ increased the PIP production by $130 \%$. As the C-peptide (PIP) dissociated from the procollagen is a measure to determine the collagen production, this data indicated that SSE possesses collagen synthesis activation activities. Cell toxicities were measured by MTT assay. As shown in Figure 2, there was no change of cell viabilities by SSE with the concentrations as high as
$100 \mu \mathrm{g} / \mathrm{mL}$. This clearly indicated that SSE's activities are not associated with cell toxicities. In order to identify the active component from the SSE, a phytochemical study was conducted. As a procedure of solvent fractionation, the ethanol extract (SSE) was partitioned into $n$-hexane, chloroform, ethyl acetate (EtOAc) and $n$-butanol portions. When the PIP contents in the solvent fractions were measured, EtOAc and $n$-butanol fractions were observed to possess collagen synthesis activation properties (data not shown). Phytochemical studies were therefore conducted for these two fractions to isolate their active constituents. As shown in Figure 1, a series of chromatographic purification procedures led to isolation of the compounds $\mathbf{1}$ and $\mathbf{2}$.

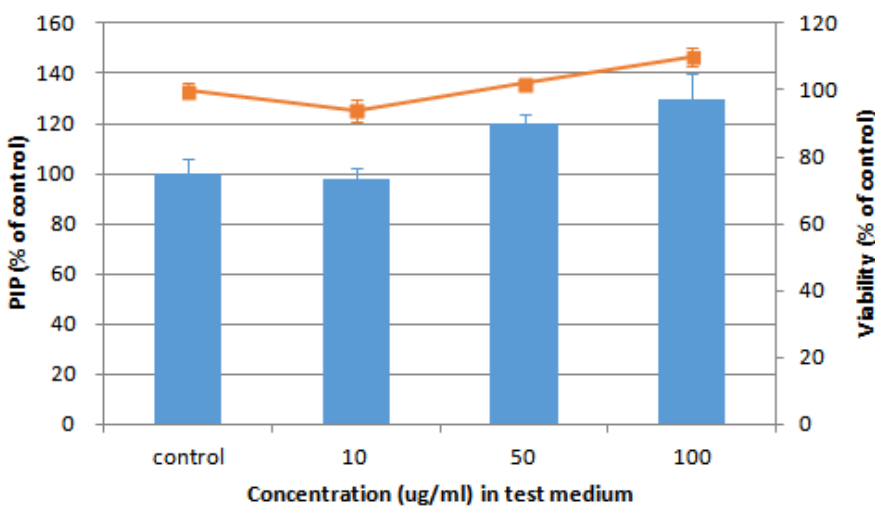

Fig. 2: Effect of the S. sieboldiana ethanol extract (SSE) on procollagen type I C-peptide (PIP) synthesis and cell toxicities. HDFn cells ( 5 x 104 cells) were incubated overnight, and procollagen type I C-peptide (PIP) was assayed after treatment of the extract (SSE) according to the supplier's instructions (Takara, MK101). The cell viability was determined by the MTT assay.<smiles>O=c1c(OC2OC(OC(CO)C3(O)C(O)C(O)C(O)C3O)C(O)C(O)C2O)c(-c2ccc(O)cc2)oc2cc(O)cc(O)c12</smiles>

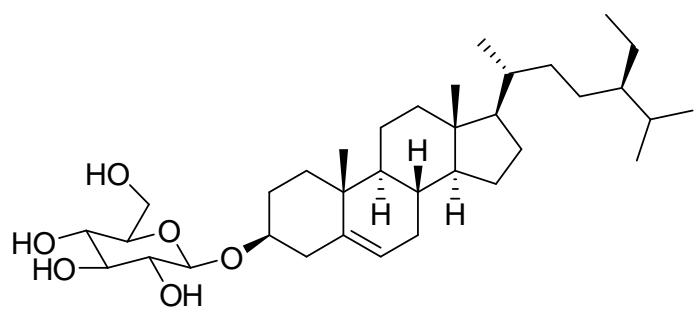

2

Fig. 3: Chemical structures of compounds 1 and $\mathbf{2}$ isolated from S. sieboldiana.

Chemical structures for compounds $\mathbf{1}$ and $\mathbf{2}$ were identified primarily by using nuclear magnetic resonance (NMR) spectroscopy (Figure 3). Compound 1 showed ortho-coupled aromatic proton signals at $\delta 8.08(2 \mathrm{H}, \mathrm{d})$ and $6.89(2 \mathrm{H}, \mathrm{d})$ with coupling constant of $7.7 \mathrm{~Hz}$ in ${ }^{1} \mathrm{H}$ NMR spectrum. In addition, 
signals for meta-coupled aromatic protons appeared at $\delta 6.37(1 \mathrm{H}$, $\mathrm{d}, J=1.8 \mathrm{~Hz})$ and $6.18(1 \mathrm{H}, \mathrm{d}, J=1.8 \mathrm{~Hz})$. Two anomeric proton signals were observed at $\delta 5.32(1 \mathrm{H}, \mathrm{d}, J=6.8 \mathrm{~Hz})$ and $4.74(1 \mathrm{H}$, $\mathrm{d}, J=6.4 \mathrm{~Hz}$ ), which suggest the presence of two glucose units in $\beta$-configurations in 1. ${ }^{13} \mathrm{C}$ NMR spectrum exhibited $15 s p^{2}$ carbon peaks $\left(\delta 179.9-94.9 \mathrm{ppm}\right.$ ) for the flavonoid skeleton and $12 s p^{3}$ carbon peaks for two molecules of sugar. Further examination of the NMR data verified that $\mathbf{1}$ has a flavonol kaempferol as an aglycon and a glucose dimer where glucoside bond was formed at C-2''. Compound 1 was therefore identified as kaempferol 3-Osophoroside, and this structure was confirmed by comparing the observed data to the literature values (Tung et al., 2010). Compound 2 showed five methyl peaks at $\delta 1.00,0.95,0.91,0.87$ and 0.67 in the ${ }^{1} \mathrm{H}$ NMR spectrum. ${ }^{13} \mathrm{C}$ NMR spectrum also indicated the presence of five methyl carbons showing signals at $\delta$ $12.3,12.5,19.3,19.5$ and $19.8 \mathrm{ppm}$. Carbon signals at $\delta_{\mathrm{C}} 122.3$ and $141.2 \mathrm{ppm}$ suggested the presence of a $\mathrm{C}=\mathrm{C}$ bond. A glucose unit was identified as a $\beta$-form by a coupling constant $7.7 \mathrm{~Hz}$ at $\delta$ 5.09 in the ${ }^{1} \mathrm{H}$ NMR spectrum. Based on all of these data, compound 2 was identified as a sterol glycoside, daucosterol (Yayli et al., 2003). Compounds 1 and $\mathbf{2}$ were isolated for the first time from $\mathrm{S}$. sieboldiana.

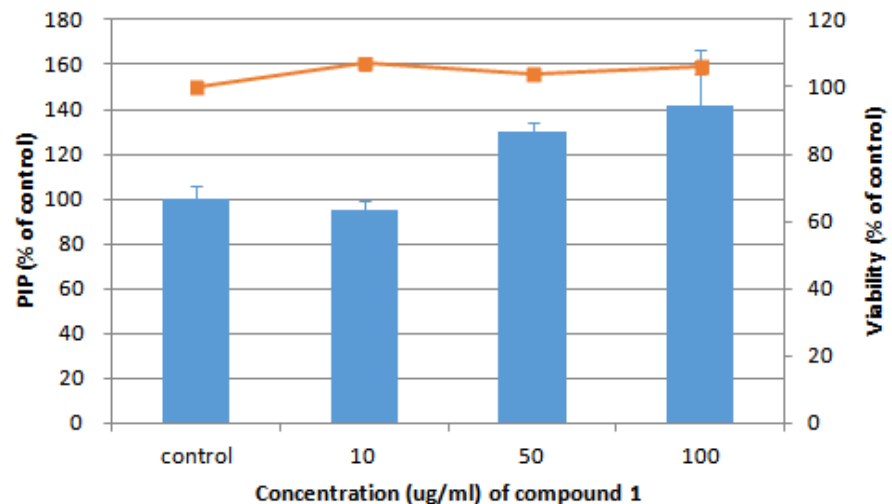

Fig. 4: Effect of the compound 1 on collagen type I synthesis and cytotoxicities. HDFn cells (5 x 104 cells) were incubated overnight, and procollagen type I C-peptide (PIP) was assayed after treatment of the compound $\mathbf{1}$ according to the supplier's instructions (Takara, MK101). The cell viability was determined by the MTT assay.

The production of procollagen by the isolated compounds $\mathbf{1}$ and $\mathbf{2}$ was monitored using the human fibroblast cells (HDFn). In this assay, the flavonoid $\mathbf{1}$ was verified to increase the PIP production dose-dependently as shown in Figure 4. Compound 1 was examined at concentrations of 10, 50 and 100 $\mu \mathrm{g} / \mathrm{mL}$ and was observed to activate the PIP production by $142 \%$ at $100 \mu \mathrm{g} / \mathrm{mL}$. Compound $\mathbf{1}$ was subjected to the MTT assay to determine whether it would induce any change in the cell viabilities and no cytotoxicities were observed at concentrations up to $100 \mu \mathrm{g} / \mathrm{mL}$ (Figure 4). The daucosterol (2) did not exhibit any activities on PIP production in the fibroblast cell culture test.

In summary, ethanol extracts were prepared from branches of a plant Sambucus sieboldiana var. pendula, and were examined for collagen synthesis activities using fibroblast HDFn cells. In this assay, the extract (SSE) proved to activate the production of type I procollagen by $130 \%$ at $100 \mu \mathrm{g} / \mathrm{mL}$ while maintaining cell viabilities. The active constituents in the extracts were isolated by chromatographic purifications and identified as kaempferol 3-O-sophoroside (1) and daucosterol (2). Among the isolates, the flavonoid glycoside $\mathbf{1}$ was verified to increase collagen production dose-dependently. These results suggested that S. sieboldiana extract containing the flavonoid $\mathbf{1}$ has a potential for use as an anti-aging ingredient in cosmetic formulations.

\section{REFERENCES}

Baumann L. 2002. Cosmetic Dermatology, Principles and Practice, McGraw-Hill Co. New York.

Brigstock DR. The CCN family, A new stimulus package. J Endocrinol, 2003; 178:169.

Cho SH, Chung ZM, Kim CJ. Analgesic and Anti-inflammatory Activity of Sambucus sieboldiana Water Extract. Chung-Ang J Pham Sci, 1994; 8:57-65.

Ko HJ, Kim GB, Lee DH, Lee GS, Pyo HB. The effects of hydrolyzed Jeju Ulva pertusa on the proliferation and type I collagen synthesis in replicative senescent fibroblasts. J Soc Cosmet Scientists Korea 2013; 39:177.

Lee GW, Park SM, Yoo YC, Cho YH. Effect of Ponrici fructus extracts fermented with Ganoderma lucidum on the collagen synthesis and expression of matrix metalloproteinase-1. Korean Soc Biotechnol Bioengin J 2013; 28:106.

Shuster S, Black MM, McVitie E. The influence of age and sex on skin thickness, skin collagen and density. Br J Dermatol 1975; 93:639.

Tung NH, Son JH, Cho KW, Kim JA, Hyun JH, Kang HK, Song GY, Park CJ, Kim YH. Phenolic Components from the Leaves of Panax ginseng and their Effects on HL-60 Human Leukemia Cells. Food Sci Biotechnol 2010; 19(1):271-274.

Yayli N, Yildirim N, Usta A, Ozkurt S, Akgun V, Chemical Constituents of Campanula lactiflora. Turk J Chem 2003; 27:749-755.

How to cite this article:

Lee NH, Yim JH, Jang MS, Moon MY, Lee HY, Kim SC. Constituents from the Branches of Sambucus sieboldiana var. pendula with the Properties of Collagen Synthesis Activation. J App Pharm Sci, 2015; 5 (04): 119-122. 